\title{
The Effect of Self-Service Technology, Service Quality, and Relationship Marketing on Customer Satisfaction and Loyalty
}

\author{
Ludfi Djajanto ${ }^{1}$, Umar Nimran ${ }^{2}$, Srikandi Kumadji ${ }^{3}$, Kertahadi ${ }^{4}$ \\ ${ }^{1}$ Accounting Department, State Polytechnic of Malang, Indonesia \\ ${ }^{2,3,4}$ Faculty of Administrative Sciences, Brawijaya University, Indonesia
}

\begin{abstract}
This research was motivated by the increasing number of people who use banking services and the fact that the society is increasingly critical in choosing a bank, especially banking services. Bank seeks to improve the range of facilities and marketing activities in order to attract customers to avail banking services. Every bank needs to give high attention to customer loyalty factors due to the high competition within banking industries. The purpose of this research was to examine the relationship among self-service technology (SST), service quality, and relationship marketing on customer satisfaction and loyalty. Samples of the study were 201 respondents of a state bank in East Java-Indonesia who have experienced using self-service technology. The Partial Least Square (PLS) was used to analyze the data and the hypotheses. Results of this study indicate that self-service technology, service quality and relationship marketing significantly effected on customer satisfaction. Furthermore, relationship marketing significantly effected on customer loyalty. However this study could not prove the effect of the self-service technology and service quality on customer loyalty.
\end{abstract}

Keywords: customer loyalty, customer satisfaction, relationship marketing, service quality, self-service technology

\section{INTRODUCTION}

Rapid development of banking industries in Indonesia may indicate the increasing number of people who use banking services. These customers should also increasingly be more critical in choosing a bank, particularly associated with banking services. This situation results in the increasingly fierce competition in the banking sector, so that most banks in Indonesia try to keep on innovating their products and services offered to customers. The bank requires its own creativity to introduce new products or services to customers. To support the success in the competition, banks are currently working hard to improve the range of facilities and marketing activities in order to attract customers to avail banking services. Most banks try to maintain the loyalty of its customers through promotion, especially by offering interesting programs as the appreciation for the bank's customers. In addition, competition in the banking sector has an impact on the high propensity of customers to easily switch to another bank (Srinivasan, 1996). Banks which are less responsive to face competition and changes in consumer desires will be easily abandoned by their customers.

Oliver (1996) argued that customer loyalty is the commitment of the customers to repurchase a product or service consistently in the future although there are situations which potentially cause change in behavior such as influences of other people or marketing efforts conducted by competitors. Banks always strive to maintain loyal customers so that they do not move to other competitors (Griffin, 2005). Currently, customer loyalty and satisfaction become very important for the bank, and this has been studied and discussed in a lot of research and literature. Prasad and Aryasri (2008) argued that marketing can consistently identify customer satisfaction as well as be a key to customer loyalty. In addition, customer satisfaction can provide many benefits for the company because higher level of customer satisfaction will result in greater customer loyalty (Lovelock and Wright, 2007). In addition, Bowen and Chen (2001) stated that having satisfied customers is not enough; there must be very satisfied customers because customer satisfaction leads to loyalty which becomes the core of the company's marketing objectives. Sivadass and Baker-Prewitt (2000) believed that the ultimate goal of customer satisfaction measurement should be customer loyalty. Fornell (1992) argued that high customer satisfaction will result in high loyalty. A study by Mohsan et al. (2011) found that customer satisfaction is positively correlated with customer loyalty and negatively correlated with the intention of customers to switch. This is also supported by research conducted by Espejel et al. (2008), showed that customer satisfaction positively influenced and significantly impacted on customer loyalty.

In general, providing high quality of services to customers is very important because without good quality of service, it is difficult for banks to satisfy or obtain the customers loyalty. Tjiptono and Chandra (2005) stated that the benefits of service quality were to create greater loyalty, greater market share, and greater productivity. There are two main factors of service quality that may affect the service that are expected service and perceived service, so that both are affected by poor quality of the service provider's ability to consistently meet customer expectations (Parasuraman et al., 1985). Some banks are racing to improve the quality of service, 
but if it is not accompanied by implementing a relationship marketing strategy, then it would be difficult to compete with other banks. Subkhan (2012) stated that loyalty which was not followed by increase in the quality of relationship and partnership with customers may result in lower customer loyalty. There is now a change in the paradigm of marketing with emphasis on transactions (transactional marketing) into marketing that focuses on maintaining long-term relationships with customers or build relationships and constructive attention to customers (relationship marketing) for long-term marketing success (Too et al., 2000). Successful implementation of relationship marketing was proven by Ndubisi's study (2007) as well as Gilaninia et al. (2011) whose results showed that there was a significant effect of relationship marketing strategy on customer loyalty.

The success of a bank in maintaining its customers to remain loyal to the bank depends on the implementation of marketing strategies such as product innovation, the provision of self-service technology that prioritizes user-friendly and fast service provision which can be done through electronic banking (e-banking), promotion, and improvement of service quality (Kurniasih, 2012). In addition, some banks from year to year always increase the number of ATMs and self-service facilities, and other technology to support electronic banking services aimed at satisfying customers. Ganguli and Roy (2011) in their research showed that four dimensions of quality service generic in technology- based banking services, including customer service, security technology and quality information, simplicity technology, and technology simplicity use and reliability. These four dimensions would positively influence customer satisfaction and customer loyalty. This is supported by the study of Buell et al. (2010) which stated that the use of self-service technology (SST) would influence customer satisfaction and retention as well as the switching cost. Proenca and Rodrigues (2011) also found that the users of self-service technology (such as ATMs, telephone banking, and internet banking) were more satisfied with the service provided by their banks compared to non-users of self-service technology. In addition, users of self-service technology of banks were more likely to express positive worth of mouth than non-users of self-service technology.

The purpose of this study was to analyze and explain the influence of self-service technology, service quality, relationship marketing on customer satisfaction and loyalty.

\section{LITERATURE REVIEW AND HYPOTHESES}

\subsection{Self-Service Technology}

Currently, handling day to day banking operations cannot be separated from the use of computer technology in order to achieve effectiveness and efficiency, especially in meeting the demands of customers. The application of technology such as self-service technology (SST) in on-line banking system, internet banking, mobile banking, mobile phone-based (phone banking), the use of Automatic Teller Machine (ATM) is one of bank's strategies in retaining and satisfying customers and in creating a competitive advantage in an effort to compete with other banks. According to Bobbitt and Dabholkar (2001) rapid use of technology in selfservice technology indicates that consumers have changed how they access various services, including accessing banking services. This is evident from the growing number of products or services using technology and the growth of the role of technology in a manufacturer-customer interaction which has been very rapid since the beginning of the 21st century (Parasuraman, 2000; Howard and Worboys, 2003). In addition, Devlin (2005) stated that the banking industry is one of the pioneers in the adoption of automation services as providers recognized as technology innovation in banking services which provide opportunities to differentiate themselves from competitors. Specifically, banks with enthusiastic adopted self-service technology of various types, including automatic teller machines (ATMs), telephone banking, internet banking, and mobile banking or SMS banking, all of which could be utilized by customers independently to meet their needs without having to interact with bank employees (Meuter et al., 2000). Therefore, the following hypotheses are proposed:

\section{H1: Self-service technology significantly effect on customer satisfaction} H2: Self-service technology significantly effect on customer loyalty

\subsection{Service Quality}

Service quality, especially in the banking sector, largely determines the success of a bank in retaining customers and in an effort to gain new customers, guaranteeing the service quality and becoming a priority for most banks. Zeithaml (1988) stated that service quality was a consumer's judgment about a product's overall excellence. Parasuraman et al. (1988) conceptualized service quality as the consumer's evaluation based on the comparison between customer expectations against perceived performance. The Service Quality Gaps Model and the SERVQUAL scale proposed by Parasuraman et al. $(1985,1988)$ are widely accepted tools for measuring service quality. Service quality evaluation did not depend solely on the outcome quality of the service but it also involved evaluation of the process of service delivery. These components had a strong effect on future expectations of a bank service but the relative impact of each might vary from one service encounter to the other 
(Bitner, 1990). In a subsequent research, Parasuraman et al. (1988) proposed five dimensions for measuring service quality, namely tangible, reliability, responsiveness, assurance, and empathy. In fact, some studies hints at ways of managing service quality in relation with increasing levels of customer satisfaction (Jones et al., 2007; Ranaweera and Prabhu, 2003). Therefore, the following hypotheses are proposed:

H3: Service quality significantly effect on customer satisfaction

H4: Service quality significantly effect on customer loyalty

\subsection{Relationship Marketing}

Dewi et al. (2008) argued that there was now a change in the paradigm of marketing with emphasis on transactions (transactional marketing) into marketing that focused on maintaining long-term relationships with customers or build relationships and constructive attention to the customer for the long-term marketing success (relationship marketing). The success of a company or a bank is not only to offer advantages that exist in the products or services offered but also depends on the suitability of the products or services offered by the consumer who wanted to be able to meet customer's needs. One marketing success can be achieved by implementing marketing strategies involving the company and its customers. This can be done by implementing customer relationship marketing, or commonly known as relationship marketing (Too et al., 2000). In the application of relationship marketing, there are several dimensions that must be taken into account to ensure that the marketing strategy by means of relationship marketing can be said successful and achieving goals. Ndubisi (2007) revealed that there were four dimensions of relationship marketing, namely to build trust, commitment, communication and conflict handling. Calonius (1988) argued that the responsibilities of marketing did not only give promises or persuade customers as passive counterparts in the marketplace, but also in keeping promises, which maintained and enhanced evolving relationship. Furthermore, Reichheld and Sasser (1990) found that fulfilling promises that have been given is equally important as a means of achieving customer satisfaction. Therefore, the following hypotheses are proposed:

\section{H5 : Relationship marketing significantly effect on customer satisfaction}

H6 : Relationship marketing significantly effect on customer loyalty

\subsection{Customer Satisfaction}

With the increasingly intense levels of competition among banks, there is intense race to provide high level of satisfaction to customers. Giving satisfaction to customers is very important and is the key in creating customer loyalty because banks will get a lot of benefit from the achievement of a high level of satisfaction. In addition to preventing customers switching to other banks, a high level of satisfaction may also be provided in order to reduce customer sensitivity to price, which may reduce service costs and, in turn, improve the reputation of marketing failures (Fornell, 1992). This can create high customer loyalty that will create the worth of mouth regarding the banks' good reputation. Getting satisfaction as expected, customers will express high level satisfaction which can be the step of managing customers to create realistic expectations (Jones et al., 2003). Furthermore, Ranaweera and Prabhu (2003) added that if customers were increasingly satisfied of products and services provided by the company, they would increasingly be motivated to be loyal.

Fecikova (2004) stated that the key to the sustainability of an organization or company is the persistence of satisfaction perceived by internal and external customers. For this reason, the performance of the company is determined in part by the level of customer loyalty where customer loyalty is influenced by the (driven) customer satisfaction (Anderson et al., 1994; Bowen and Chen, 2001; Fornell et al., 1996). This is supported by Lovelock et al. (1998) who revealed that customer satisfaction would provide many benefits for the company and the level of customer satisfaction would result in higher customer loyalty. According to Kotler and Susanto (2000), customer satisfaction can be defined as the level of one's feelings after comparing the performance or results which the customer felt to their expectations. If performance is below the expectations of the customer, the customer will be disappointed while if performance exceeds expectations, the customer will feel very satisfied. Engel et al. (1990) argued that customer satisfaction is the after-service evaluation where the chosen alternative at least equals to or exceeds customer expectations. Otherwise, dissatisfaction will arise if the results are not as expected. According to Jamal and Naser (2002), customer satisfaction can be measured by using indicators that include: very satisfied, meets expectations, and performance. Therefore, the following hypothesis is proposed:

\section{H7 : Customer satisfaction significantly effect on customer loyalty}




\subsection{Customer Loyalty}

In the era of globalization, expectations for companies and banks to be able to continue growing can be concentrated on creating loyal customers. This makes companies and banks try to create a competitive advantage through innovative efforts and creativity to retain loyal customers. Oliver (1996) defined customer loyalty as the commitment of the customers to repurchase a product or service consistently in the future, although there are situations which potentially cause change in behavior such as influences of other people or marketing efforts conducted by competitors. Guiltinan et al. (1997) also found that satisfied customers were more likely to repeat purchase of products or services and even become loyal customers and not to think of switching to another banks.

\section{CONCEPTUAL FRAMEWORK}

The conceptual framework of this study was based on the previous studies examining the effect or linkage of self-service technology, service quality, and relationship marketing on customer satisfaction and loyalty as shown in Figure 1.

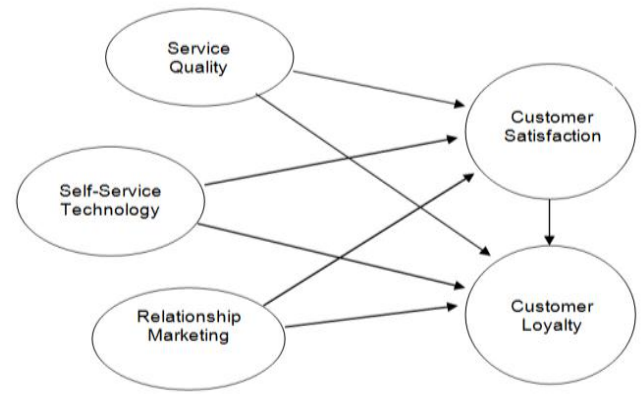

Figure 1 Diagram of Conceptual Framework

\section{METHODS}

The research was conducted at a state bank whose branches were located in seven cities in East Java, Indonesia. This research was an explanatory research because it explained the causal relationship between the study variables and hypotheses test (Singarimbun and Effendi, 2011). This research examined the effect and the relationship between the variables, including the self - service technology, service quality, relationship marketing, customer satisfaction and customer loyalty.

Sampling was done by random sampling method, which was proportional cluster sampling technique based on region selection. The sample size was allocated proportionally, in which each member of the population had an equal chance to be elected as members of the sample. This research was conducted at the users of self-service technology (ATMs, SMS banking, mobile phone banking or internet banking) who had become bank customers for at least two years. Sample size in this study was 204 people, including customers of state bank in seven cities in East Java, Indonesia: Surabaya, Malang, Kediri, Jember, Madiun, Blitar, and Pasuruan. Total number of questionnaires distributed was 225 questionnaires which was $10 \%$ larger than the number of the expected respondents. However, of the 225 questionnaires, there were 201 returned and completely filled out. Thus, the unit of analysis in this study was 201. In this study, the measurement scale used in the questionnaire was based on the five points of the Likert Scale, where each question was given a score of 1 to 5. The data analysis technique used was the analysis of Partial Least Square (PLS).

\subsection{Description of Respondents}

\section{RESULTS AND DISCUSSION}

Description of the respondent's identity was obtained through questionnaires. The description of the users of self-service technology consists of: gender, education, occupation, income, duration being banks' customer as shown in Table 1.

Table 1: Respondent Description

\begin{tabular}{|l|c|c|c|}
\hline No. & Description & Total & Percentage \\
\hline 1 & Sex & & 54,7 \\
\hline & a. Male & 110 & 45,3 \\
\hline & b. Female & 91 & \\
\hline 2 & Education Level & 8 & 4,0 \\
\hline & a. Under Senior high school & 15 & 7,5 \\
\hline & b. Senior high school & 32 & 15,9 \\
\hline & c. Diploma (D1-D3) & 81 & 40,3 \\
\hline
\end{tabular}


The Effect of SST, Service Quality and Relationship Marketing on Customer Satisfaction and Loyalty

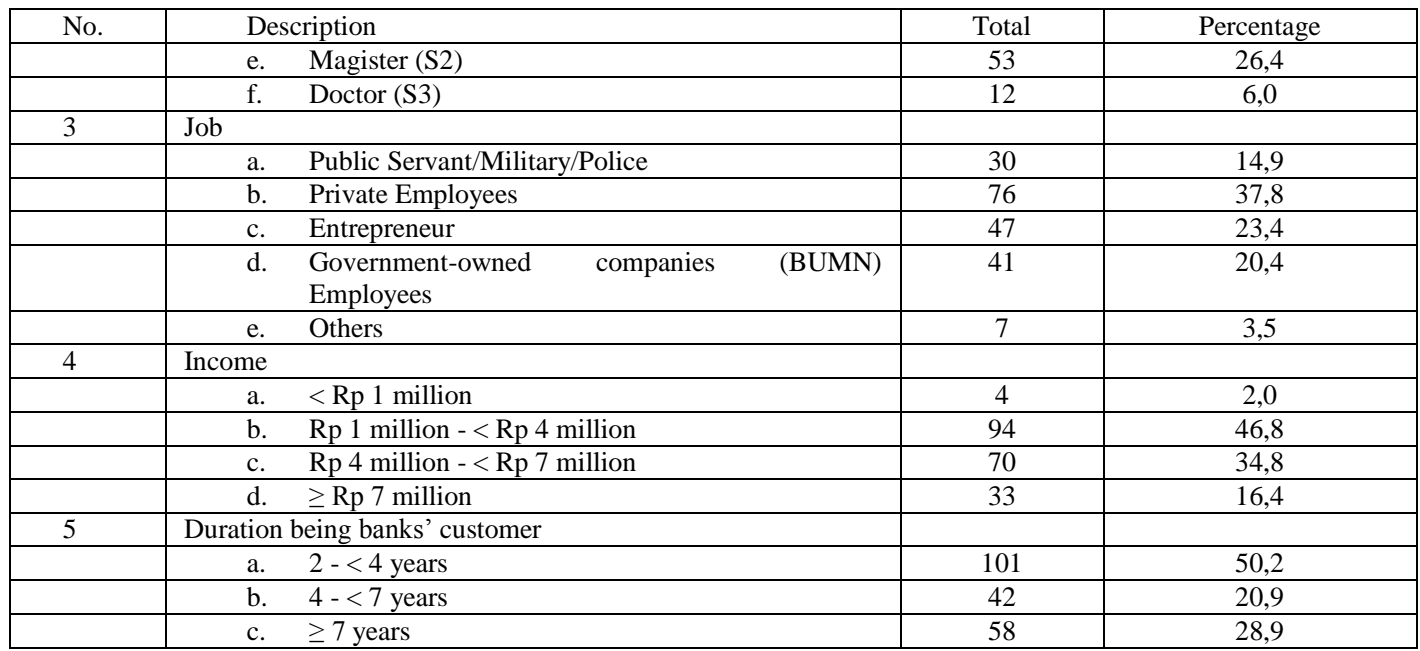

\subsection{Measurement Model (Outer Model)}

The measurement model used to test the construct validity and reliability of the instrument in the PLS was done by:

\section{Validity of Formative Indicators}

Examination of the validity of the instrument for the formative indicators in the study was done by the significance of the outer weight as shown in Table 2.

Table 2: Validity of Formative Indicators Test Result on $X_{1}$ and $X_{2}$

\begin{tabular}{|l|c|c|}
\hline Variables / Indicators & Outer Weight & p-value \\
\hline Self Service Technology $\left(\mathrm{X}_{1}\right)$ & 0.7557 & 0.0000 \\
\hline $\mathrm{X}_{1.1}$ & 0.7356 & 0.0000 \\
\hline $\mathrm{X}_{1.2}$ & 0.7444 & 0.0000 \\
\hline $\mathrm{X}_{1.3}$ & 0.8038 & 0.0000 \\
\hline $\mathrm{X}_{1.4}$ & 0.7799 & 0.0000 \\
\hline $\mathrm{X}_{1.5}$ & \multicolumn{3}{|l|}{} \\
\hline Service Quality $\left(\mathrm{X}_{2}\right)$ & 0.5939 & 0.0000 \\
\hline $\mathrm{X}_{2.1}$ & 0.6798 & 0.0000 \\
\hline $\mathrm{X}_{2.2}$ & 0.6940 & 0.0000 \\
\hline $\mathrm{X}_{2.3}$ & 0.7119 & 0.0000 \\
\hline $\mathbf{X}_{2.4}$ & 0.7819 & 0.0000 \\
\hline $\mathrm{X}_{2.5}$ & & \\
\hline
\end{tabular}

Based on Table 2, all indicators have p-value $<0.05$, so the indicators are significant. The research instrument can be said to be valid.

2. Convergent validity

As well as formative indicator models, the reflective indicator for variable $X_{3}, Y_{1}$, and $Y_{2}$, check of the convergent validity of the instrument was done by looking at significant outer loading as shown in Table 3 .

Table 3: Convergent Validity Test Results of Reflective Indicators $X_{3}, Y_{1}$, and $Y_{2}$

\begin{tabular}{|l|c|c|}
\hline \multicolumn{1}{|c|}{ Variables / Indicators } & Outer Loading & p-value \\
\hline Relationship Marketing $\left(\mathrm{X}_{3}\right)$ & 0.8280 & 0.0000 \\
\hline $\mathrm{X}_{3.1}$ & 0.8040 & 0.0000 \\
\hline $\mathrm{X}_{3.2}$ & 0.7772 & 0.0000 \\
\hline $\mathrm{X}_{3.3}$ & 0.6984 & 0.0000 \\
\hline $\mathrm{X}_{3.4}$ &
\end{tabular}




\begin{tabular}{|l|c|c|}
\hline \multicolumn{1}{|c|}{ Variables / Indicators } & Outer Loading & p-value \\
\hline Customer Satisfaction $\left(\mathrm{Y}_{1}\right)$ & 0.6691 & 0.0000 \\
\hline $\mathrm{Y}_{1.1}$ & 0.7656 & 0.0000 \\
\hline $\mathrm{Y}_{1.2}$ & 0.8113 & 0.0000 \\
\hline $\mathrm{Y}_{1.3}$ & 0.6996 & 0.0000 \\
\hline $\mathrm{Y}_{1.4}$ & 0.7618 & 0.0000 \\
\hline $\mathrm{Y}_{1.5}$ & & 0.0000 \\
\hline${\text { Customer Loyalty }\left(\mathrm{Y}_{2}\right)}^{\mid}$ & 0.7553 & 0.0000 \\
\hline $\mathrm{Y}_{2.1}$ & 0.7451 & 0.0000 \\
\hline $\mathrm{Y}_{2.2}$ & 0.7846 & 0.0000 \\
\hline$Y_{2.3}$ & 0.7459 & \\
\hline$Y_{2.4}$ & & \\
\hline
\end{tabular}

Based on Table 3, all indicators have p-value $<0.05$, so the indicators are significant. The research instrument can be said to be valid.

\section{Discriminant validity}

This measurement compares the cross loading of each indicator value of a variable with the value of the indicator cross loading on other variables. If the value of the variable in question cross loading is greater than the discriminant indicator, it is valid as shown in Table 4, where it can be seen that the discriminant validity was met.

Table 4: Results of Discriminant Validity Test: Cross Loading

\begin{tabular}{|c|c|c|c|c|c|}
\hline & $\begin{array}{c}\mathrm{X}_{1}=\text { Self- } \\
\text { Service } \\
\text { Technology }\end{array}$ & $\begin{array}{c}\mathrm{X}_{2}=\text { Service } \\
\text { Quality }\end{array}$ & $\begin{array}{c}\mathrm{X}_{3}=\text { Relationship } \\
\text { Marketing }\end{array}$ & $\begin{array}{c}Y_{1}=\text { Customer } \\
\text { Satisfaction }\end{array}$ & $\begin{array}{c}\mathrm{Y}_{2}=\text { Customer } \\
\text { Loyalty }\end{array}$ \\
\hline $\mathrm{X}_{1.1}$ & 0.755707 & 0.285661 & 0.298551 & 0.533762 & 0.244837 \\
\hline $\mathrm{X}_{1.2}$ & 0.735642 & 0.347841 & 0.358413 & 0.529593 & 0.224867 \\
\hline $\mathrm{X}_{1.3}$ & 0.744376 & 0.343548 & 0.355539 & 0.433017 & 0.366028 \\
\hline$X_{1.4}$ & 0.803799 & 0.354351 & 0.364895 & 0.452971 & 0.414921 \\
\hline $\mathrm{X}_{1.5}$ & 0.779867 & 0.318143 & 0.386500 & 0.428299 & 0.417627 \\
\hline $\mathrm{X}_{2.1}$ & 0.259743 & 0.593877 & 0.440224 & 0.270738 & 0.331719 \\
\hline $\mathrm{X}_{2.2}$ & 0.271401 & 0.679753 & 0.454311 & 0.341927 & 0.341285 \\
\hline $\mathrm{X}_{2.3}$ & 0.260488 & 0.693981 & 0.483940 & 0.365877 & 0.328299 \\
\hline $\mathrm{X}_{2.4}$ & 0.365947 & 0.711869 & 0.383212 & 0.417564 & 0.286118 \\
\hline $\mathrm{X}_{2.5}$ & 0.317126 & 0.781884 & 0.495408 & 0.421254 & 0.359058 \\
\hline $\mathrm{X}_{3.1}$ & 0.513672 & 0.485667 & 0.827969 & 0.512479 & 0.382241 \\
\hline$X_{3.2}$ & 0.342144 & 0.505443 & 0.803980 & 0.421246 & 0.334250 \\
\hline $\mathrm{X}_{3.3}$ & 0.350571 & 0.572869 & 0.777229 & 0.490703 & 0.373840 \\
\hline $\mathrm{X}_{3.4}$ & 0.218217 & 0.362658 & 0.698400 & 0.302138 & 0.466516 \\
\hline $\mathrm{Y}_{1.1}$ & 0.451639 & 0.260658 & 0.276987 & 0.669076 & 0.250431 \\
\hline $\mathrm{Y}_{1.2}$ & 0.488961 & 0.417660 & 0.409961 & 0.765569 & 0.336605 \\
\hline $\mathrm{Y}_{1.3}$ & 0.503459 & 0.416768 & 0.467297 & 0.811283 & 0.395318 \\
\hline $\mathrm{Y}_{1.4}$ & 0.386093 & 0.510199 & 0.489473 & 0.699644 & 0.519343 \\
\hline $\mathrm{Y}_{1.5}$ & 0.449463 & 0.370091 & 0.398923 & 0.761752 & 0.470303 \\
\hline $\mathrm{Y}_{2.1}$ & 0.522051 & 0.352177 & 0.460605 & 0.521608 & 0.755308 \\
\hline $\mathrm{Y}_{2.2}$ & 0.236743 & 0.341558 & 0.322473 & 0.309424 & 0.745149 \\
\hline $\mathrm{Y}_{2.3}$ & 0.276524 & 0.311776 & 0.352505 & 0.384176 & 0.784566 \\
\hline $\mathrm{Y}_{2.4}$ & 0.256776 & 0.365684 & 0.336676 & 0.383186 & 0.745918 \\
\hline
\end{tabular}

\section{Composite reliability (pc)}

Reflective indicators that measure composite variables have good reliability if it has a composite reliability $>0.7$ as shown in Table 5 . 
Table 5: Composite Reliability Test Results

\begin{tabular}{|l|c|}
\hline \multicolumn{1}{|c|}{ Variables } & Composite Reliability \\
\hline $\mathrm{X}_{3}=$ Relationship Marketing & 0.844 \\
\hline $\mathrm{Y}_{1}=$ Customer Satisfaction & 0.860 \\
\hline $\mathrm{Y}_{2}=$ Customer Loyalty & 0.859 \\
\hline
\end{tabular}

Table 5 shows that based on the reliability test results with the composite reliability of the research instrument, it can be said that the data were reliable due to all the variables tested were with composite reliability $>0.7$.

\subsection{Analysis of Research Findings}

Validity of an indicator can be seen from the value of its loading. For explorative study, validity indicator value of 0.5 to 0.6 is considered sufficient (Chin, 1998). While reliability is a measure of the internal consistency of the indicators of a variable, indicating the degree to which each indicator variable indicates a common formation. The reliability using composite (construct) reliability is with a minimum cut-off value of 0.7. However, for an exploratory study, reliability value of between $0.5-0.6$ is considered reliable (Ferdinand, 2005).

The criteria used to test the model fit (Goodness-of-fit) was the R-square $\left(\mathrm{R}^{2}\right)$ for the dependent latent variable with the same interpretation of the regression (Mateos and Morales, 2011). $R^{2}$ was used to determine how much variance in the construct can be explained by the model whereas the structural path coefficient using t-test statistics were obtained from the bootstrapping procedure (Ghozali, 2006). Output measurement model with PLS is shown in Figure 2.

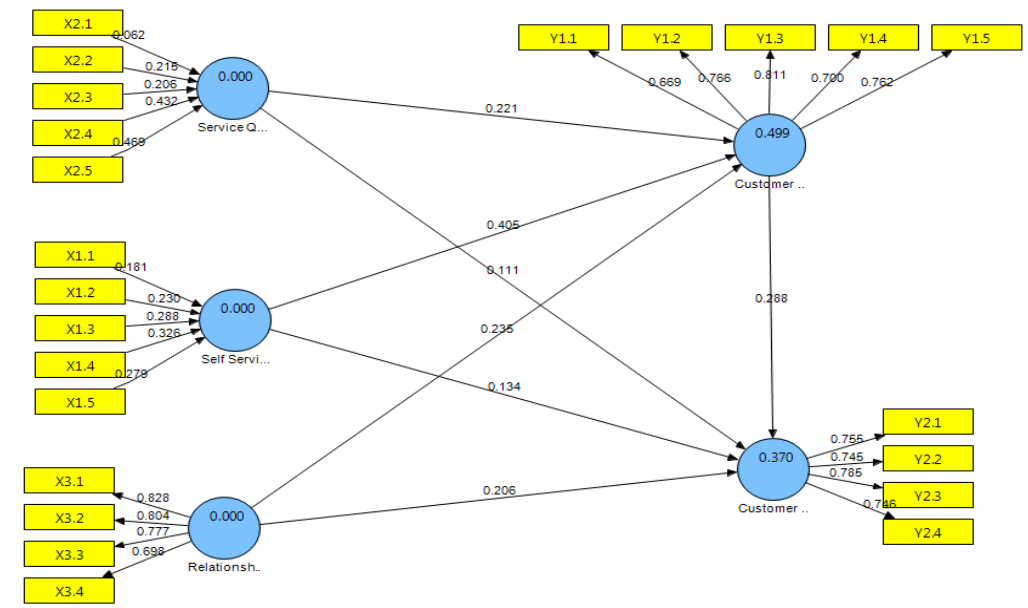

Figure 2 Output Measurement Model with PLS

\subsection{Linearity Assumption Test Results}

Linearity test was used in order to determine the linearity of the relationship between exogenous variables to endogenous variables, and also to be able to determine the significance level of deviation from linearity of the relationship. Where irregularities were found to be significant, then the relationship between exogenous variables to the endogenous variables was linear. The meaning of linearity assumption is the assumption that will determine whether the data used in the study are in accordance with the linear line or not (Lestari, 2013). Results of testing the linearity assumption in this study are shown in Table 6.

Table 6: Linearity Assumption Test Results

\begin{tabular}{|c|l|l|c|c|}
\hline No. & \multicolumn{2}{|c|}{ Relationships between variables } & Linearity & Description \\
\hline 1 & Self-Service Technology $\left(\mathrm{X}_{1}\right)$ & Customer Satisfaction $\left(\mathrm{Y}_{1}\right)$ & 0.000 & Linear \\
\hline 2 & Self-Service Technology $\left(\mathrm{X}_{1}\right)$ & Customer Loyalty $\left(\mathrm{Y}_{2}\right)$ & 0.000 & Linear \\
\hline 3 & Service Quality $\left(\mathrm{X}_{2}\right)$ & Customer Satisfaction $\left(\mathrm{Y}_{1}\right)$ & 0.000 & Linear \\
\hline 4 & Service Quality $\left(\mathrm{X}_{2}\right)$ & Customer Loyalty $\left(\mathrm{Y}_{2}\right)$ & 0.000 & Linear \\
\hline 5 & Relationship Marketing $\left(\mathrm{X}_{3}\right)$ & Customer Satisfaction $\left(\mathrm{Y}_{1}\right)$ & 0.000 & Linear \\
\hline 6 & Relationship Marketing $\left(\mathrm{X}_{3}\right)$ & Customer Loyalty $\left(\mathrm{Y}_{2}\right)$ & 0.000 & Linear \\
\hline 7 & Customer Satisfaction $\left(\mathrm{Y}_{1}\right)$ & Customer Loyalty $\left(\mathrm{Y}_{2}\right)$ & 0.000 & Linear \\
\hline
\end{tabular}


Linearity test is often required as a prerequisite to perform correlation analysis or linear regression. Linearity test using the test for linearity at significance level of 0.05 , then the two variables are said to have a linear relationship when significance (linearity) is less than $0.05(\mathrm{p}<0.05)$ or in other words, the linearity is met if the $\mathrm{p}$-value of the linearity $\mathrm{F}$ value is less than $0.05(\mathrm{p}<0.05)$.

Table 6 shows that the F-test resulted in a significant test, because the p-value of all the variables tested are less than $0.05(\mathrm{p}<0.05)$, means that the relationship between variables in this study are linear, so that the linearity assumption is met.

\subsection{Goodness of Fit Model}

Examination the goodness of fit models in the analysis of PLS by calculating the $\mathrm{Q}^{2}$ based on R square. Value of R-square obtained throughout the coefficient of determination of all the endogenous variables, and in the models in this study, there are two endogenous variables, namely customer satisfaction $\left(\mathrm{Y}_{1}\right)$ and customer loyalty $\left(\mathrm{Y}_{2}\right)$. The coefficients of determination $\mathrm{R}^{2}$ of dependent variables are presented as Table 7 .

Table 7: Goodness of fit models

\begin{tabular}{|c|l|c|}
\hline No. & \multicolumn{1}{|c|}{ Dependent variables } & R-square \\
\hline 1 & Customer Satisfaction $\left(\mathrm{Y}_{1}\right)$ & 0.629453 \\
\hline 2 & Customer Loyalty $\left(\mathrm{Y}_{2}\right)$ & 0.384564 \\
\hline
\end{tabular}

Based on Table 7, the value of $\mathrm{Q}^{2}$ can be calculated as follows:

$$
\begin{aligned}
\mathrm{Q}^{2} & =1-\left(1-\mathrm{R}_{1}^{2}\right)\left(1-\mathrm{R}_{2}^{2}\right) \ldots\left(1-\mathrm{R}_{\mathrm{n}}^{2}\right) \\
\mathrm{Q}^{2} & =1-(1-0.629)(1-0.385) \\
& =0.7718
\end{aligned}
$$

$\mathrm{Q}^{2}$ value of research is at 0.7718 or $77.18 \%$, to explain the empirical phenomenon assessed by $77.18 \%, 22.82 \%$ while the rest of the model is influenced by other variables that are not observed in this study. $\mathrm{Q}^{2}$ value close to 1 is relatively high, which indicates that the model can be said to be good.

\subsection{Hypotheses Testing}

Based on empirical models proposed in this study, the analysis was done using the Partial Least Square (PLS). Hypotheses testing were done by t-test, and those are summarized in Table 8.

Table 8: Research Hypotheses Testing Results

\begin{tabular}{|c|l|l|c|c|c|}
\hline No. & \multicolumn{2}{|c|}{ Relationships between variables } & $\begin{array}{c}\text { Path } \\
\text { Coefficient }\end{array}$ & p-value & Description \\
\hline 1 & Self-Service Technology $\left(\mathrm{X}_{1}\right)$ & Customer Satisfaction $\left(\mathrm{Y}_{1}\right)$ & 0.4046 & 0.0000 & Significant \\
\hline 2 & Self-Service Technology $\left(\mathrm{X}_{1}\right)$ & Customer Loyalty $\left(\mathrm{Y}_{2}\right)$ & 0.1335 & 0.1659 & No significant \\
\hline 3 & Service Quality $\left(\mathrm{X}_{2}\right)$ & Customer Satisfaction $\left(\mathrm{Y}_{1}\right)$ & 0.2214 & 0.0027 & Significant \\
\hline 4 & Service Quality $\left(\mathrm{X}_{2}\right)$ & Customer Loyalty $\left(\mathrm{Y}_{2}\right)$ & 0.1108 & 0.2187 & No significant \\
\hline 5 & Relationship Marketing $\left(\mathrm{X}_{3}\right)$ & Customer Satisfaction $\left(\mathrm{Y}_{1}\right)$ & 0.2349 & 0.0037 & Significant \\
\hline 6 & Relationship Marketing $\left(\mathrm{X}_{3}\right)$ & Customer Loyalty $\left(\mathrm{Y}_{2}\right)$ & 0.2056 & 0.0299 & Significant \\
\hline 7 & Customer Satisfaction $\left(\mathrm{Y}_{1}\right)$ & Customer Loyalty $\left(\mathrm{Y}_{2}\right)$ & 0.2881 & 0.0024 & Significant \\
\hline
\end{tabular}

Of the overall testing, results show that the relationship between two variables is not significant while five other paths are significant. The hypotheses rejected or not significantly influenced were those regarding the effect of self-service technology on customer loyalty and the effect of service quality on customer loyalty.

\subsection{Discussion}

\subsubsection{Effect of Self-Service Technology on Customer Satisfaction}

Results of the analysis were the path coefficient $=0.4046$ with $\mathrm{p}$-value $=0.0000(\mathrm{p}<0.05)$, then the test results can be said to be significant, so that the research hypothesis was accepted. This suggests that the self-service technology significantly effected on customer satisfaction. The results of this study support the research conducted by Mols (1998); Fornell (1992); Meuter et al. (2000); Bitner et al. (2002) who proved the relationship of self-service technology on customer satisfaction. As expressed by Gerson (2001), customer satisfaction originates from customer expectations. In dealing with the bank, of course, there are some customers' expectations in service, for examples: speed, security and ease of service. Manual service sometimes creates problems, remembering the delivery queue that is inevitably slow. Thus, there is a gap between the expectations and reality of service received by the customer. Self-service technology is actually the answer to fill that gap. Customers who want speed service at a competitive cost would be very grateful in responding the application of self-service technology. 
Thus, this study has demonstrated that self-service technology can influence customer satisfaction. Based on Engel et al. (1990) that customer satisfaction is the after-sales service evaluation where the chosen alternative at least equals to or exceeds customer expectations. Otherwise, dissatisfaction will arise if the results are not as expected. Furthermore, Fecikova (2004) stated that the key to the sustainability of a company is the persistence of satisfaction perceived by internal and external customers.

\subsubsection{Effect of Self-Service Technology on Customer Loyalty}

Wallace et al. (2004) stated that groove interactions doubles, including transactions carried out in selfservice media, has been shown to lead to positive disconfirmation, which in turn was found to lead to increased satisfaction and loyalty. Results of the analysis were the path coefficient $=0.1335$ with p-value $=0.1659$ (p> 0.05 ), then the test results can be said to be not significant. Therefore, the research hypothesis was rejected. These findings suggest that self-service technology does not significantly direct effect on customer loyalty. These results do not support studies conducted by Mol (1998) and Wallace et al. (2004). Thus, the relationship between self-service technology and loyalty was not a direct relationship, but the relationship was more indirect. These findings support research conducted by Proenca and Rodrigues (2011) that customer satisfaction with banking services based on self-service technology will increase loyalty. This finding confirms that the design of self-service technology should lead to efforts to satisfy customers not only in the orientation of the efficiency for the bank. Furthermore, Buell et al. (2010) who examined the effect of using self-service technology on the retention (synonymous with loyal behavior) showed no significant results. The findings further confirmed that the application of self-service technology must be oriented on customer service in order to satisfy the long-term impact on loyalty.

\subsubsection{Effect of Service Quality on Customer Satisfaction}

Oliver (1993) stated that service quality is a determination factor causing customer satisfaction. Parasuraman, Zeithaml and Berry $(1985 ; 1988 ; 1990 ; 1994)$ also stated that the higher the perceived level of service quality, the greater customer satisfaction. The results of the analysis were the path coefficient $=0.2214$ with $\mathrm{p}$-value $=0.0027(\mathrm{p}<0.05)$, then the test results can be said to be significant so that the research hypothesis was accepted. This suggests that the service quality significantly effected on customer satisfaction. The results of the analysis support the research conducted by Oliver (1993) and Parasuraman, Zeithaml and Berry (1985; 1988; 1990 and 1994) who were able to prove the influence of service quality on customer satisfaction. Customer satisfaction will contribute directly to the creation of switching barriers, switching costs and customer loyalty (Tjiptono and Chandra, 2005).

\subsubsection{Effect of Service Quality on Customer Loyalty}

Services quality provided by the banks are expected to meet the needs of customers in particularly associated with efforts to improve customer satisfaction as expressed by the Hosts and Andersen (2004) that from the analysis of price and service quality effect on customer loyalty through customer fulfillment. The results of the analysis were the path coefficient $=0.1108$ with $p$-value $=0.2187(p>0.05)$, then the test results can be said to be not significant so that the research hypothesis was rejected. This suggests that service quality did not significantly effect on the customer loyalty. This is contradictory to the results of research studies by Host and Andersen (2004) that proved the existence of the effect of service quality on customer loyalty. These findings indicated that customer loyalty is a form of behavior that can accept customer after customer with satisfactory service so that the relationship between service quality and loyalty is not a direct relationship; rather, the relationship requires a form of intervening other variables. This study finds that customer satisfaction is a mediating variable proved (intervening) linking quality service with customer loyalty. This is in line with the research conducted by Hosts and Andersen (2004) that proved the effect of service quality on customer loyalty through customer satisfaction.

\subsubsection{Effect of Relationship Marketing on Customer Satisfaction}

In the world of banking, relationship marketing is not solely related on how to retain customers for mutual benefit, but also one of the better ways to get to know the background of the customer so that the banks can meet the needs and desires of its customers (Alma, 2009). The results of the analysis were the path coefficient $=0.2349$ with $\mathrm{p}$-value $=0.0037(\mathrm{p}<0.05)$, then the test results can be said to be significant so that the research hypothesis was accepted. This indicates that the relationship marketing significantly effected on customer satisfaction. The results of this study support the research by Moorman et al. (1992); Morgan and Hunt (1994) who proved that necessary to achieve mutual satisfaction maintain valuable relationships. The findings of this study also support the research conducted by Gilaninia et al. (2011); Juscius and Grigaite (2011) which shows that the relationship marketing has an influence on customer satisfaction. Some of the important elements in the relationship marketing include: trust, communication, commitment and conflict resolution need to be 
considered by the bank. If the elements of marketing relationship can be done well, it will have an impact on customer satisfaction.

\subsubsection{Effect of Relationship Marketing on Customer Loyalty}

Berry (1983) stated that relationship marketing is attracting, retaining and in multi-service organizations improve customer relationships. Results of the analysis were the path coefficient $=0.2056$ with pvalue $=0.0299(\mathrm{p}<0.05)$, then the test results can be said to be significant, so that the research hypothesis was accepted. This indicates that the relationship marketing significantly effected on customer loyalty. The results of this study support the research conducted by Berry (1983) that the relationship marketing can strengthen customer relationships and turn into customer loyalty. Implementation of the overall dimensions that exist in relationship marketing is aiming to give satisfaction to the consumer as a service user. With the satisfaction of the service users, it is expected to increase loyalty towards the bank. Elu (1997) stated that the benefits to be gained when implementing relationship marketing is the establishment of cooperation with customers in the long term, as well as the opportunity to sell other products or services or a new one to the same customer so that customer loyalty is formed.

\subsubsection{Effect of Customer Satisfaction on Customer Loyalty}

Oliver (1999) argued that customer satisfaction and loyalty are interconnected. Therefore, customer satisfaction significantly effected on customer loyalty (Bloemer et al., 1998). Several researchers revealed that customer satisfaction positively influenced on customers loyalty (Oliver, 1999; Zeithaml et al., 1996). In addition, Fornell (1992) stated that customer satisfaction would lead to an increase in customer loyalty, so that customers would be more vulnerable to bid from competitors. The results of the analysis were the path coefficient $=0.2881$ with $\mathrm{p}$-value $=0.0024(\mathrm{p}<0.05)$, then the test results can be said to be significant, so that the research hypothesis was accepted. This study demonstrated that customer satisfaction significantly effected on customer loyalty. The results of this study support the research conducted by Oliver (1999) and Zeithaml et al. (1996). In addition, Fornell (1992) were able to prove the influence of customer satisfaction on customer loyalty. Customer loyalty became a strong competitive component to retain customers because it was not easily imitated by competitors. Bowen and Chen (2001) argued that having satisfied customers was not enough prior to the establishment of customer satisfaction leads to loyalty which the core of the bank marketing purposes.

\section{CONCLUSION}

The results of this study indicate that self-service technology, service quality and relationship marketing have a significant effect on customer satisfaction. Similarly, relationship marketing has a significant effect on customer loyalty, but self-service technology and service quality do not significantly effect on customer loyalty. This research has a contribution that is related to the self-service technology, confirming research by Meuter et al. (2000) and Dabholkar (1996). This study also confirms research by Bitner (1990), Grönroos (1990), Parasuraman et al. (1988) regarding service quality. In addition, the findings related to relationship marketing also confirm the research conducted by Sin et al. (2002) and Ndubisi (2007). Results regarding customer satisfaction confirm the study by Caruana and Malta (2002); Jamal and Naser (2002) while the research of customer loyalty confirms a study by Baloglu (2002).

This study has several limitations, such as limitations on survey methods that use only the questionnaires, so that respondents in filling out questionnaires based on their perception and can lead to bias responses. This was because respondents might give untrue answers but they believed to be appropriate. In addition, the questionnaires were not fully able to dig up information like open-ended questions, so that additional information for the completeness of discussion was still needed to be developed further. This study was only conducted in one state bank alone, so that research results can not represent the general banking customer satisfaction and loyalty.

\section{REFERENCES}

[1] Srinivasan, Madhav. 1996. "New Insights into Switching Customer Behavior". Journal of Marketing Research. Vol. 8 No. 3: 27-28.

[2] Oliver, Richard. 1996. Satisfaction a behavior perspective on the customer. Mc Graw Hill. New York.

[3] Griffin, Jill. 2005. Customer Loyalty. Erlangga. Jakarta

[4] Prasad, Ch. J. S. and A. R. Aryasri. 2008. Study of customer relationship marketing practices in organized retailing in food and grocery sector in India: An empirical analysis. The Journal of Business Perspective. Vol. 12 No. 4: 33-43.

[5] Lovelock, Christopher H. and L.K. Wright. 2007. Service Marketing Management. Prentice-Hall, Inc. New Jersey. Diterjemahkan oleh Agus Widyantoro dan tim. 2005. Manajemen Pemasaran Jasa. Cetakan ke 2. PT. Macanan Jaya Cemerlang. Jakarta.

[6] Bowen, J.T. and S.I. Chen. 2001. " The relationship between Customer loyalty and customer satisfaction". International Journal of contemporary Hospitality Management. Vol.13. No. 5: 213-217.

[7] Sivadass, E. and J.L. Baker-Prewitt. 2000. "An Examination of the Relationship between Service Quality, Customer Satisfaction, and Store Loyalty". International Journal of Retail \& Distribution Management, 28 (2): 73-82.

[8] Fornell, C., 1992. A national customer satisfaction barometer: the Swedish experience. J. Mark., 56: 6-21. 
[9] Mohsan, Faizan, M.M. Nawaz, M. S. Khan, Z. Shaukat, and N. Aslam. 2011. "Impact of Customer Satisfaction on Customer Loyalty and Intentions to Switch: Evidence from Banking Sector of Pakistan". International Journal of Business and Social Science. Vol. 2 No. 16. September: 263-270.

[10] Espejel, Joel, Carmina Fandos and Carlos Flavian. 2008. "Consumer satisfaction a key factor of consumer loyalty and buying intention of a PDO food product”. British Food Journal. Vol. 110. No. 9: 865-881.

[11] Tjiptono, Fandy dan G. Chandra. 2005. Service, Quality \& Satisfaction. Penerbit Andi. Yogyakarta.

[12] Parasuraman, A., V.A. Zeithaml, and L.L. Berry. .1985. "A conceptual model of service quality and its implications for future research', Journal of Marketing, Vol. 49: 41-50.

[13] Subkhan, Farid. 2012. "Empat Tahap Mengukur Indeks Loyalitas". Infobank. No. 394. Vol. XXXIII. Januari: $22-23$.

[14] Too, Leanne H.Y, Souchon Anne L, and Thirkell Peter C., 2000. "Relationship Marketing and Customer Loyalty in A Retail Setting: A Dyadic Exploration". Aston Bussines School Research Institute. June: 1-36.

[15] Ndubisi, Nelson O., 2007. "Relationship marketing and customer loyalty". Marketing Intelligence \& Planning. Vol. 25 No. 1: 98106.

[16] Gilaninia, Shahram, H. Shahi and S.J. Mousavian. 2011. "The Effect of Relationship Marketing Dimensions by Customer Satisfaction to Customer Loyalty". Interdisciplinary Journal of Contemporary Research in Business. Vol. 3. No. 4. August: 74-84.

[17] Kurniasih, Apriyani. 2012. "Penabung BCA Masih Paling Loyal". Infobank. No. 394. Vol. XXXIII. Januari: $24-28$.

[18] Ganguli, Shirshendu and S.K. Roy. 2011. "Generic technology-based service quality dimensions in banking Impact on customer satisfaction and loyalty". International Journal of Bank Marketing. Vol. 29 No. 2: 168-189.

[19] Buell, Ryan W., Campbell D. and F.X. Frei. 2010. “Are Self-Service Customers Satisfied or Stuck?”. Production and Operations Management Journal. Vol. 19, No. 6, November-December: 679-697.

[20] Proenca, Joao F. and M.A. Rodrigues. 2011. A comparison of users and non-users of banking self-service technology in Portugal. Managing Service Quality. Vol. 21 No. 2: 192-210.

[21] Bobbitt, L. and P. Dabholkar. 2001. "Integrating attitudinal theories to understand and predict use to technology-based self-service. The internet as an illustration". International Journal of Service Industry Management, Vol. 12. No. 5: 423-50.

[22] Parasuraman, A., 2000. "Technology readiness index (TRI): a multiple-item scale to measure readiness to embrace new technologies", Journal of Service Research, Vol. 2 No. 4: 307-20.

[23] Howard, M. and C. Worboys. 2003. "Self-service - a contradiction in terms or customer-led choice?", Journal of Consumer Behavior, Vol. 2 No. 4: 382-92.

[24] Devlin, J., 1995. "Technology and innovation in retail banking distribution", International Journal of Bank Marketing, Vol. 13 No. 4: 19-25.

[25] Meuter, M.L., A.L. Ostrom, R.I. Roundtree, and M.J. Bitner. 2000. "Self-service technologies: understanding customer satisfaction with technology-based service encounters", Journal of Marketing, Vol. 64 No. 3: 50-64.

[26] Zeithaml, Valerie A., 1988. "Consumer Perceptions of Price, Quality, and Value: A Means-End Model and Synthesis of Evidence", Journal of Marketing, Volume 52, Number 3: 2-22.

[27] Parasuraman, A, V.A. Zeithami and L.L Berry. 1988. " A Multiple-Item Scale for Measuring Consumer Consumer Perceptions of Service Quality,” Journal of Retailing, Vol.64: 12-40.

[28] Bitner, M. J. 1990. "Evaluating Service Encounters: The Effects of Physical Surroundings and Employee Responses." Journal of Marketing 54(2): 69-82.

[29] Jones, M.A., Reynolds, K.E., Mothersbaugh, D.L. and Beatty, S.E. 2007. "The positive and negative effects of switching costs on relational outcomes". Journal of Service Research. Vol. 9 (4): 335-55.

[30] Ranaweera, C. and Prabhu, J. 2003. "The influence of satisfaction, trust and switching barriers on customer retention in a continuous purchase setting”. International Journal of Service Industry Management. Vol. 14 (4): 374-95.

[31] Dewi, N.I.K., C. G. P. Yudistira dan G. Santanu. 2008. "Pendekatan Relationship Marketing untuk Loyalitas Pelanggan: Kasus Denpasar Front Office Qantas Airways di Bali”. Jurnal Sarathi. Vol. 15 No. 1. Januari: 114-128.

[32] Calonius, H. 1988. "A buying process model". Proceedings of the XVII Annual Conference of the European Marketing Academy on Innovative Marketing. University of Bradford: 86-103.

[33] Reichheld, F.E. and Sasser, W.E. Jr. 1990. "Jr Zero defections: Quality comes to service”. Harvard Business Review.Vol. 68: 105-11.

[34] Fecikova, I., 2004. "An index method of customer satisfaction". TQM Magazine. Vol. 16. No. 1: 57-66.

[35] Anderson, E.W., Claes Fornell, and R. Lehmann. 1994. "Customer Satisfaction Market Share, and Profitability: Finding from Sweden". Journal of Marketing. Vol. 58. No. 1: 53-56.

[36] Fornell, C., M.D. Johnson, E.W. Anderson, J. Cha, and B.E. Bryant. 1996. "The American customer satisfaction index: nature, purpose, and findings". Journal of Marketing, Vol. 60: 7-18.

[37] Lovelock, C. H., P. G. Patterson, dan R. H. Walter. 1998. Service Marketing: Australia and New Zealand. Prentice Hall. Sydney.

[38] Kotler, Philip dan A.B. Susanto. 2000. Manajemen Pemasaran: Analisis, Perencanaan, Implementasi, dan Pengendalian. Salemba Empat. Yogyakarta.

[39] Engel, J.F., R.D. Blackwell, and P.W. Miniard. 1990. Consumer Behavior. The Dryden Press. Orlando.

[40] Jamal, Ahmad and Kamal Naser. 2002. "Customer satisfaction and retail banking: an assessment of some of the key antacedents of customer satisfaction in retail banking". International journal of Bank Marketing. Vol. 20. No. 4: 146-160.

[41] Singarimbun, Masri dan Sofian Effendi. 2011. Metode Penelitian Survei. Cetakan keempat. Penerbit LP3ES. Jakarta.

[42] Chin, W. W. 1998. The Partial Least Squares Approach to Structural Equation Modeling. Modern Methods for Business Research. G. A. Marcoulides. Mahwah. Lawrence Erlbaum Associates. NJ.

[43] Ferdinand, A., 2005. Structural Equation Modelling dalam Penelitian Manajemen. BP-UNDIP. Semarang.

[44] Ghozali, Imam. 2006. Structural Equation Modeling, Metode Alternatif dengan Partial Least Square. Semarang, Badan Penerbit Universitas Diponegoro.

[45] Lestari, Hestu. 2013. Uji Linieritas. Statistika Pendidikan. http//:statistikapendidikan.com.

[46] Mols, P., 1998. "The behavioral consequences of PC banking”, International Journal of Bank Marketing, Vol. 16 No. 5: $195-201$.

[47] Gerson, F Richard. 2001. Mengukur Kepuasan Pelanggan. PPM. Jakarta.

[48] Wallace, D., J. Giese, J. Johnson. 2004. "Customer retailer loyalty in the context of multiple channel strategies". J. Retail. 80(4): 249- 263.

[49] Oliver, Richard L., 1993. "A Conceptual model of service quality and service satisfaction: compatible goals, different concept". Advance in Service Marketing and Management, Vol.2: 65-85.

[50] Parasuraman, A, V.A. Zeithami and L.L Berry. 1990. Delivering Quality Service Balancing Customer Perceptions and Expectation. The Fress Press, New York. 
[51] Parasuraman, A, V.A. Zeithami and L.L Berry. 1994. "Reassessment of Expectations as a Comparison Standar in Measuring Service Quality: Implication for Further Research“. Journal of Marketing, January (58):111-124.

[52] Host, Viggo, and Andersen, Michael Knie. 2004. "Modeling Customer Satisfaction In Mortgage Credit Companies", Emerald, The International Journal of Bank Marketing, Denmark.

[53] Alma, Buchari. 2009. Manajemen Pemasaran dan Pemasaran Jasa. Penerbit Alfabeta. Bandung.

[54] Moorman, C., G.Zaltman, and R. Deshpande. 1992. "Relationships Between Providers and Users of Marketing Research: The Dynamics of Trust Within and Between Organizations,"Journal of Marketing Research. Vol.29, August: 314-329.

[55] Morgan, Robert M and Hunt, Shelby D., 1994. "The Commitment Trust Theory of Relationship Marketing," Journal of Marketing, Vol.58, July: 20-28.

[56] Juscius, Vytautas and Viktorija Grigaite. 2011. "Relationship marketing practice in Lithuanian logistics organizations". Baltic Journal of Management. Vol. 6. No. 1: 71-88.

[57] Berry, L.L., 1983. Relationship marketing: Emerging Perspectives of Services Marketing, American Marketing Association, Chicago, IL.

[58] Elu, Wilfridus B., 1997. Membangun keunggulan melalui strategi relationship marketing. Manajemen Usahawan Indonesia. 3/THN.XXVI, Maret: 14-16.

[59] Bloemer, Josee and Ko de Ruyter. 1998. "Investigating drivers of bank loyalty: the complex relationship between image, service quality", International Journal of Bank Marketing. Volume 16. Number 6/7: 276-286.

[60] Zeithaml, Valerie A., L.L. Berry, L.L. and A. Parasuraman. 1996. "The behavioural consequences of service quality". Journal of Marketing. Vol. 60: 31-46.

[61] Dabholkar, P.A., 1996. "Consumer evaluations of new technology-based self-service options: an investigation of alternative models of service quality". International Journal of Research in Marketing. Vol. 13. No. 1: 29-51.

[62] Gronroos, Christian. 1990a. Service Management and Marketing. Lexington Books. Toronto.

[63] Gronroos, Christian. 1990b. "Relationship Approach to The Marketing Function in Service Contexts". Journal of Business Research. Vol. 29 No.1: 3-12.

[64] Sin, Leo Y.M., Tse and Yan. 2002. "The effect of relationship marketing orientation on business performance in a service oriented economy", JQSM, Vol. 16. No.7.

[65] Caruana, Albert and Malta Msida. 2002. "Service loyalty: The effect of service quality and the mediating role of customer satisfaction". European Journal of Marketing. Vol. 36. No. 7/8: 811-828.

[66] Jamal, Ahmad and Kamal Naser. 2002. "Customer satisfaction and retail banking: an assessment of some of the key antacedents of customer satisfaction in retail banking". International journal of Bank Marketing. Vol. 20. No. 4: 146-160.

[67] Baloglu, Seyhmus. 2002. "Dimensions of customer loyalty: Separating friends from well wishers". Cornell Hotel and Restourant Administration Quarterly. Vol. 43. No. 1. February: 47.

Appendix
\begin{tabular}{|l|l|}
\hline Variables & Indicators \\
\hline Self-Service Technology $\left(\mathrm{X}_{1}\right)$ & $\mathrm{X}_{1.1}=$ Ease of use \\
& $\mathrm{X}_{1.2}=$ Convenience \\
& $\mathrm{X}_{1.3}=$ Cost savings \\
& $\mathrm{X}_{1.4}=$ Safety \\
& $\mathrm{X}_{1.5}=$ Control over service provision \\
\hline Quality of Service $\left(\mathrm{X}_{2}\right)$ & $\mathrm{X}_{2.1}=$ Tangible \\
& $\mathrm{X}_{2.2}=$ Reliability \\
& $\mathrm{X}_{2.3}=$ Responsiveness \\
& $\mathrm{X}_{2.4}=$ Assurance \\
& $\mathrm{X}_{2.5}=$ Empathy \\
\hline Relationship Marketing $\left(\mathrm{X}_{3}\right)$ & $\mathrm{X}_{3.1}=$ Trust \\
& $\mathrm{X}_{3.2}=$ Communications \\
& $\mathrm{X}_{3.3}=$ Commitment \\
& $\mathrm{X}_{3.4}=$ Conflict handling \\
\hline Customer Satisfaction $\left(\mathrm{Y}_{1}\right)$ & $\mathrm{Y}_{1.1}=$ Good to be satisfied \\
& $\mathrm{Y}_{1.2}=$ Frequent use \\
& $\mathrm{Y}_{1.3}=$ Conformity to expectations \\
& $\mathrm{Y}_{1.4}=$ More performance \\
& $\mathrm{Y}_{1.5}=$ Not disappointed \\
\hline Customer Loyalty $\left(\mathrm{Y}_{2}\right)$ & $\mathrm{Y}_{2.1}=$ Psychological commitment \\
& $\mathrm{Y}_{2.2}=$ Switching cost \\
& $\mathrm{Y}_{2.3}=$ Word of mouth advertisers \\
& $\mathrm{Y}_{2.4}=$ Cooperation \\
\hline
\end{tabular}

